\title{
COVID-19 and Education Management: the Case of Silesian Region - Poland
}

\author{
Luis Ochoa Siguencia \\ Akademia Wychowania Fizycznego \\ w Katowicach \\ Katowice, Poland \\ l.ochoa@awf.katowice.pl \\ Zofia Gródek Szostak \\ Department of Economics and \\ Enterprise Organization, \\ Cracow University of Economics \\ Kraków, Poland \\ grodekz@uek.krakow.pl
}

\author{
Gilberto Marzano \\ Rezekne Academy of Technologies \\ Rezekne, Latvia \\ gilberto.marzano@rta.lv \\ Anna Szeląg-Sikora \\ Małopolska Uczelnia Państwowa \\ im. rotmistrza Witolda Pileckiego \\ w Oświęcimiu \\ Oświęcim, Poland \\ anna.szelag- \\ sikora@dydaktyk.uczelniaoswiecim
}

\author{
Renata Ochoa-Daderska \\ Instytut Badań i Innowacji \\ w Edukacji \\ r.ochoa@inbie.pl
}

\begin{abstract}
COVID-19 outbreak has changed the economic and social relations and caused a critical impact on the higher education system. The closure of University campuses to prevent community transmission of the Coronavirus SARS-CoV-2 has shifted face-to-face classes to online learning, distance learning, e-learning, mobile learning, and social learning. E-Learning and virtual education may become an essential component of the higher education system in the next years. Accordingly, teaching staff had to adapt their teaching methodology and tools to eLearning tools and platforms for effective student engagement.

This paper reports on a first study conducted from December 2020 to January 2021, involving one hundred Higher Schools teachers of Management in the Silesia Region.

The study showed many serious problems related to the emergency teaching-learning experience since it was essentially based on the translation of face-to-face approach in the online environment.
\end{abstract}

Keywords - Remote teaching-learning, e-learning, Information Technology in education, Social media.

\section{INTRODUCTION}

When COVID-19 became a global pandemic in March 2020, most school systems began closing down. Since March, universities worldwide have postponed or cancelled all campus events such as workshops, conferences, sports, and other activities. They raced to transition their courses and other educational programs from face-to-face to remote teaching.

In April, UNESCO estimated 1.5 billion students were no longer attending lessons in a physical classroom [1].

The remote teaching modality was addressed as emergency remote teaching (ERT) to underline that it was extemporary, adopted under necessity [2], and different compared to e-learning in normal circumstances.

Due to the lockdown, the situation at higher education institutions appeared immediately critical. Although quite a few of them have had already introduced Learning Management System (LMS) platforms, such as Backboard and Moodle, they were not ready to start with a massive remote teaching experience.

Accordingly, the transition to online learning created several problems forcing most of institutions to upgrade their information technology (IT) infrastructure quickly, train and support teaching staff in using software tools, and deal with new modalities for exams.

It was challenging to define suitable new procedures for administrating online courses as well as monitor students 
when they were online and ensure they do not cheat during online tests. Moreover, laboratory activities were not possible to conduct remotely, and not all students necessarily got a fast internet connection. Finally, while universities closed campuses, many students do not have any other alternative accommodation facilities.

In general, the experience of ERT showed several issues. It demonstrated that adopting an online learning environment is not just a technical question but poses pedagogical and instructional challenges $[3,4,5]$.

In the last few months, many surveys and case studies have been carried out to evaluate the impact of ERT on educational systems $[6,7,8]$. They mostly focused on the teaching staff and students' evaluation of ERT experience as well as the assessment of online teachinglearning practices.

The desk research carried out for this paper shows that:

- $\quad$ Teachers adopted in remote teaching the same modality they used in normal face-to-face modality.

- Students and teachers generally agree to continue with remote teaching-learning, but they pointed out on the disadvantage of the loss of interaction.

- Many teachers complained that students were passive, and often they switched off the webcam, claiming it slowed down the internet speed.

Data from surveys indicates that there is a general consensus that ERT has been a unique and significant experience, although the organization of remote classes and virtual exams, as well as of the various bureaucratic activities proved very challenging $[9,10,11,12,13,14$, 15]

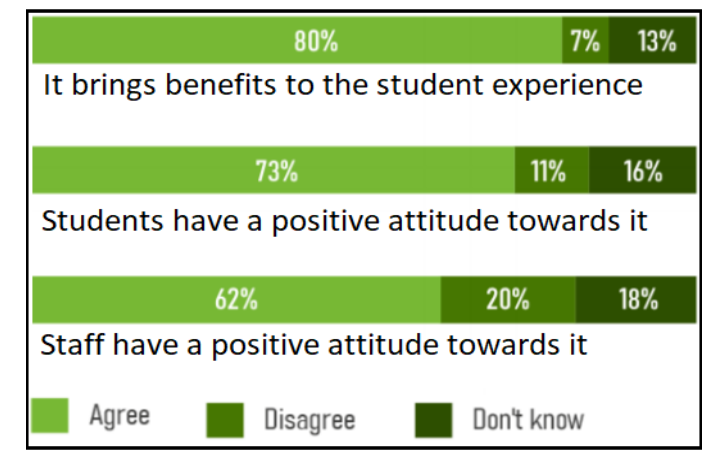

Fig 1. Position of higher education institutions towards digitally enhanced learning and teaching (source: Gaebel, Zhang, Stoeber, \& Morrisroe, 2021, p. 44)

A survey conducted from April to June 2020 by DIGIHE, a European Union co-funded project, shows (Figure
1) that, in general, acceptance by higher education institutions on digitally enhanced learning and teaching has grown, and they widely acknowledge the benefits it brings to the student experience [16].

However, ERT also brought out discrimination and psychological health issues.

A recent survey conducted by McKinsey on school teachers in several countries (Australia, Canada, China, France, Germany, Japan, the United Kingdom, and the United States) shows that teachers agree on the high cost of remote learning, especially for vulnerable students [17].

It has also been argued that remote teaching-learning caused a tremendous stress level among students with unfavourable effects on their learning and psychological health [18].

\section{METHODOLOGY}

A survey was conducted from December 2020 to January 2021, involving 100 teachers of Management in various Universities in the Silesia Region.

The questionnaire analyses the institutional support in the learning process during the early months of the Higher schools lockdown to assess and evaluate the current situation caused by COVID-19. The Google forms tool has been used to create an online questionnaire providing a hyperlink to teachers interested in participating in the survey.

The results available through Google sheets have been transferred to Statistica 13, a software developed by StatSoft, Inc.

The survey's questionnaire used both single and multiple-choice questions, while the $\chi 2$ test was used to compare observed and expected frequencies from the survey results.

\section{RESULTS AND DISCUSSION}

The teaching staff and adult educator trainers who responded to the questionnaire confirm using their PC or laptop to provide lectures and workshops during the pandemic time. Nearly all of them [87\%] affirm that they had only access to their PC for preparing their teaching materials. While $80 \%$ reportedly used their PC or Laptop for delivering the content of their lessons, only $14 \%$ used smartphones. The main reason for this low score is the difficulty of presenting the PowerPoints and other materials without using a touchpad and mouse.

$87 \%$ of respondents claimed they would like to use their laptop or PC for lessons and training, only $4 \%$ would be interested in using a business PC, and 6\% smartphones. 
Environment. Technology. Resources. Rezekne, Latvia Proceedings of the $13^{\text {th }}$ International Scientific and Practical Conference. Volume 2, 162-168

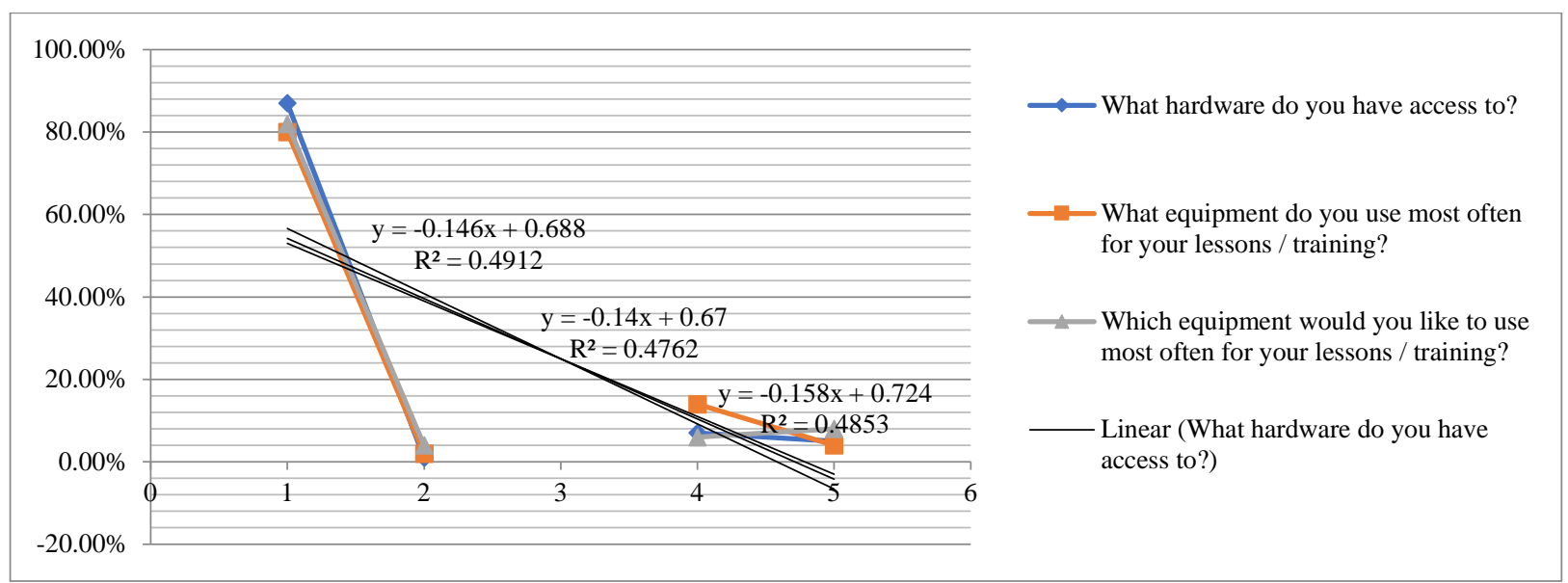

Fig 2. Tech devices used by teachers

In order to check the respondents' online behaviour, a chi2 test was carried out.

Most respondents used online libraries (91\%) for internet searches (95\%). This answer was followed by social media portals and video channels. Other digital education tools such as cloud-based software, social conferences, were not preferred as much as the other favoured options focusing on search engines, social media portals and video channels.

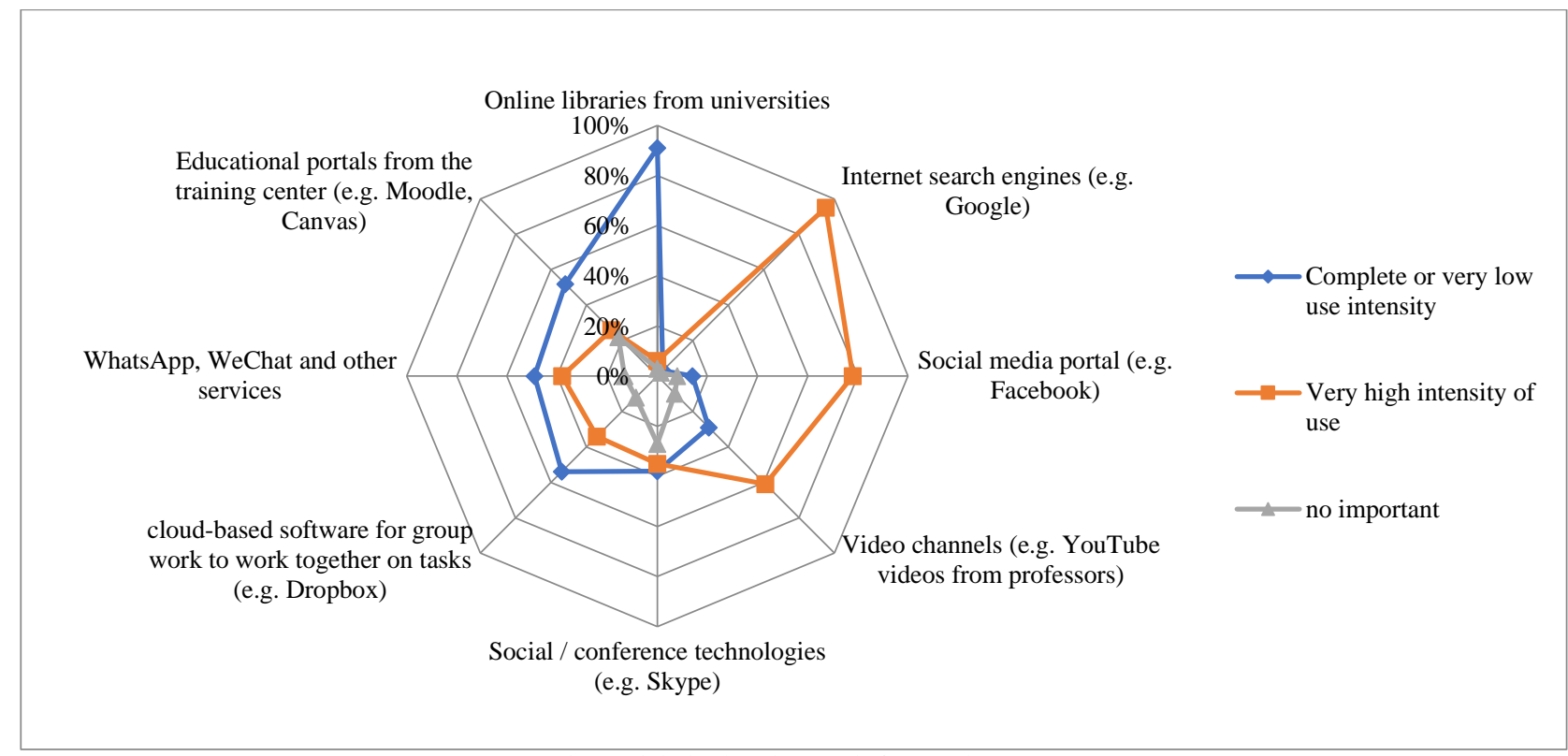

Fig 3. Digital Education Tools for Teachers

In order to communicate with the student teacher, applications such as zoom are most often used (100\%), the instructors also use social media in about (50\%), the classic form of communication such as E-mail is still often used about $60 \%$ of the time, and it is definitely more often than a phone call (20\%). For communication, teachers still use text messaging such as We chat (30\%) of the respondents. 


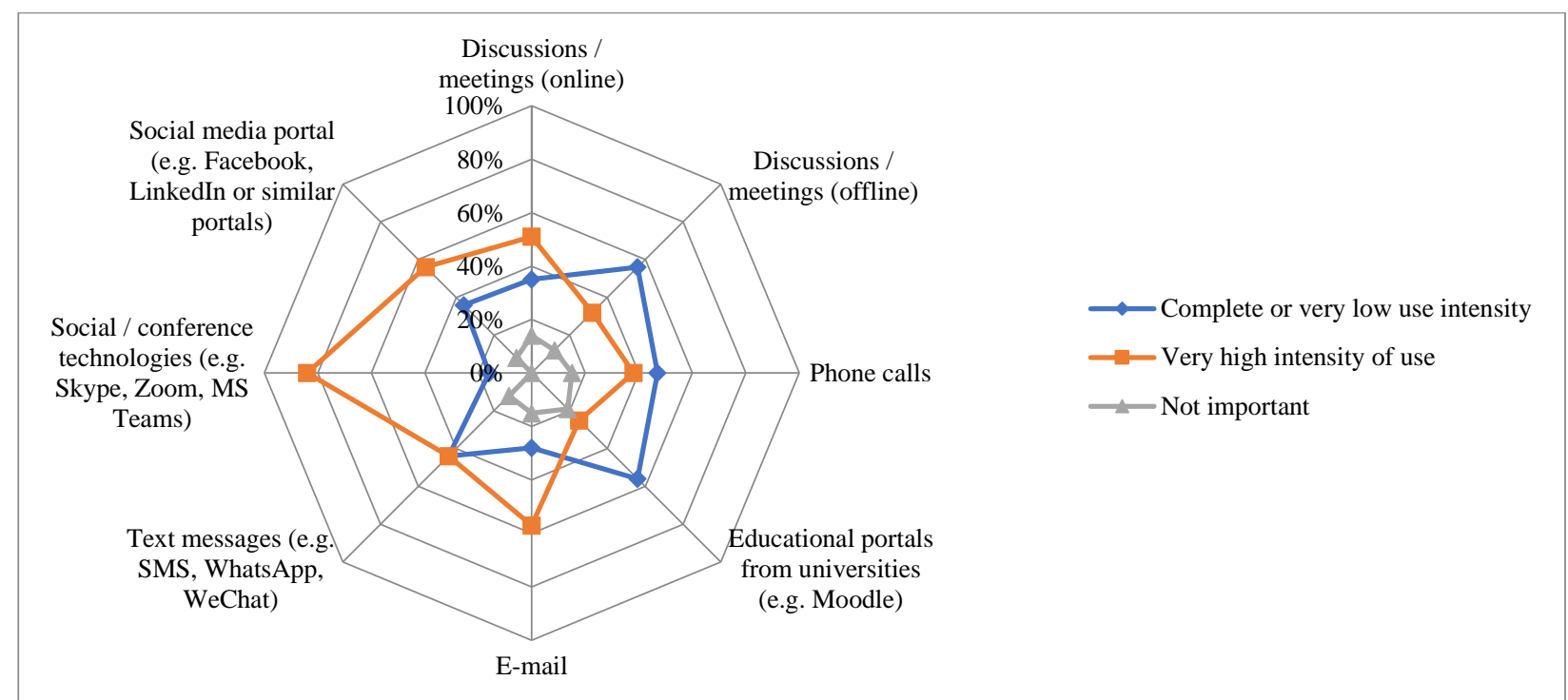

Fig 4. Technology teachers use to communicate with their course participants / students

The questionnaire also aimed to identify the institutional support in the learning process. More than half of the participants were found to be very satisfied about the possibility of using selected technologies in studies / project and communication (59\%) and their own level of competence when using technology.

Almost half of participants also found the lecturers' use of technologies that support the learning process
(47\%); however, for $31 \%$, the lecturers' use of technologies is not satisfactory.

With $44 \%$ and $42 \%$ of dissatisfaction ratios respectively, availability of university support services (e.g. IT Support Centre) and availability of information technology in an educational institution (e.g. computer lab) indicated low levels of satisfaction among the participants.

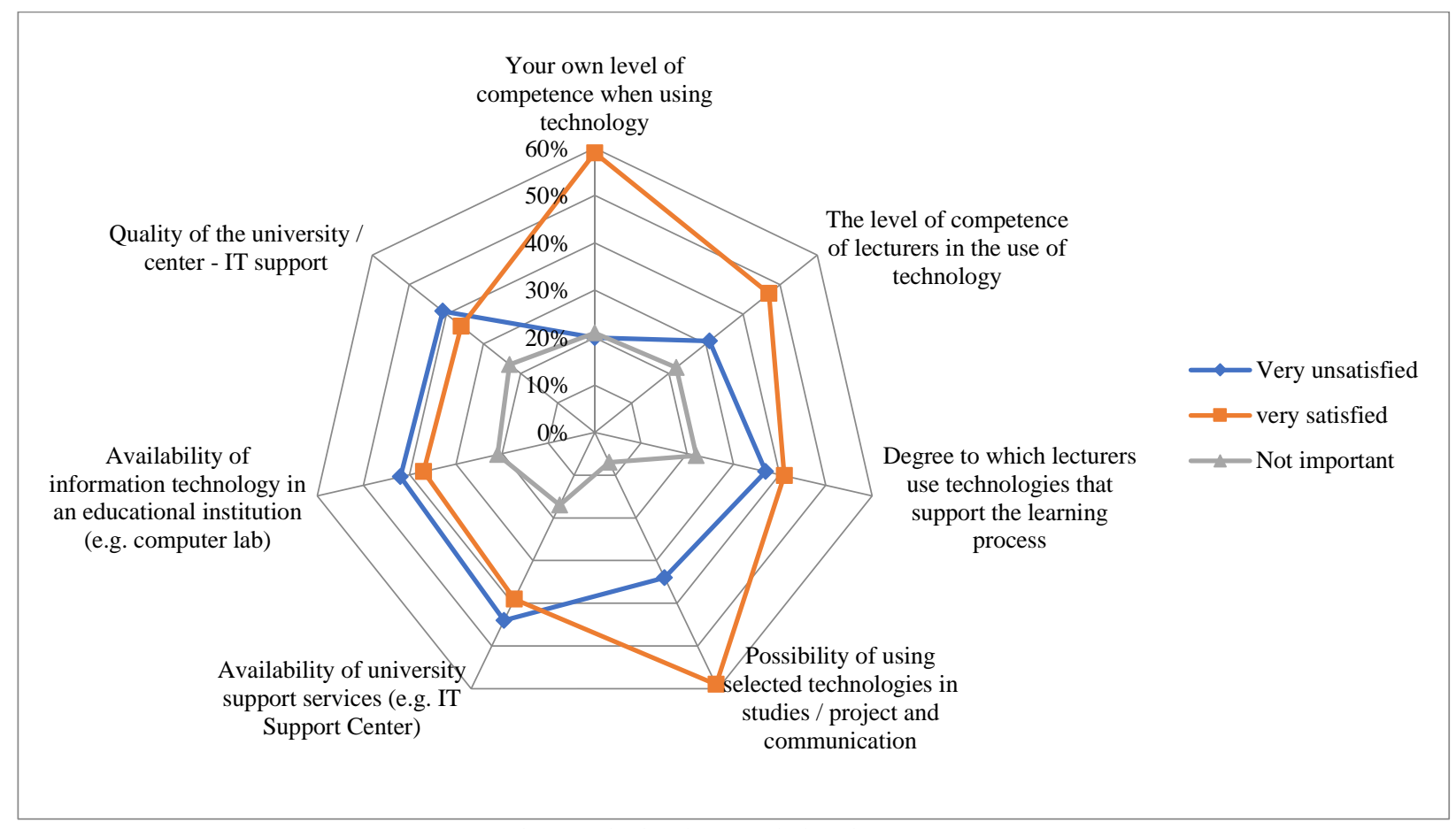

Fig 5. Institutional support in learning process 
Analysing the results, it can be concluded that the dominant social networking site is Facebook - 90\% most often people use it for every application. Another website is Instagram, most often people upload their photos 35\%, interestingly, when commenting on content, twitter $11 \%$ is used more often than Instagram $7 \%$. Summarizing the results, it can be said that the most favourite medium is the Facebook, it is the most used in each case. Then Instagram, but twitter is used for commenting.

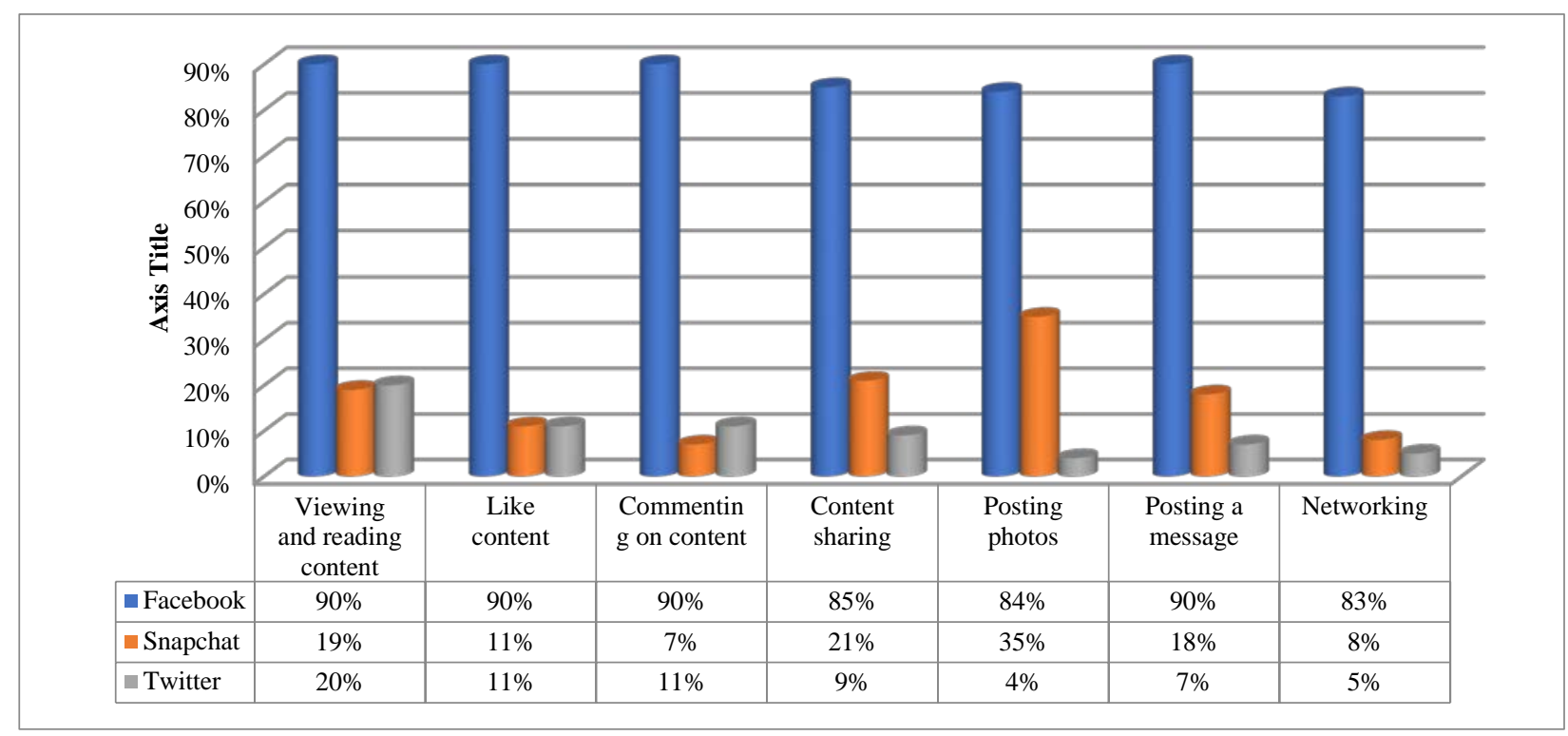

Fig 6. Social Media channels' use

The majority of respondents did not provide any information about the workplace $92 \%$ of respondents, only $8 \%$ of respondents can observe such a phenomenon. In order to learn more about the impact of corona virus on education, we recommend repeating the study after completing the pandemic. As a result, the impact on teachers and education can be better identified.

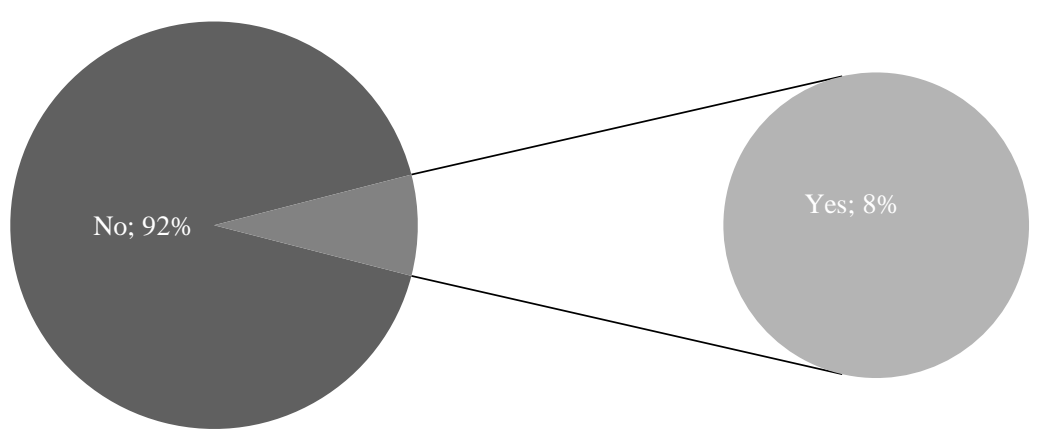

Fig 7. Placing information about the place of employment on a private profiles

\section{CONCLUSIONS}

In the current epidemiological situation, one should be particularly careful and remember sanitary and epidemiological requirements. Safety and quality of teaching must be given priority by every university; while improving the quality of educational services.
Summing up, it should be added how a vital role in teaching is played by establishing a relationship with the student - the social aspect of entering a relationship and learning.

This article showed the difficulty of establishing a relationship with students and encouraging them to participate in classes actively. 
Lack of direct contact with the teacher hinders the learning process; because classes at universities should be carried out synchronously and involve both lecturers and students. The pandemic's time had the potential to revolutionize higher education, but it failed, and faculty failed to transfer the lecture and practice model to the internet. No cameras are turned on. Students are reluctant to enter into discussions. Anonymity and onesided broadcasting of messages lower the level of higher education.

Research shows that teachers do not receive the expected support, both technical and psychological, and are left alone with the choice of tools, channels, and educational platforms. From the presented results, it emerged that students "join", for example, to the zoom platform or teams; however, they are reluctant to use contact, e.g., by phone - to establish a direct conversation with the lecturer. Despite the diagnosed and identified challenges, the COVID-19 pandemic could provide students with an impetus to exponentially develop their self-study skills.

The academic staff of universities should actively encourage students to remain resilient and able to adapt in the face of a pandemic, as this may inculcate in students the necessary attributes on the labour market, e.g. working in remote teams in organizations or virtual organizations [19]. Acquiring these traits can enable students to deal with uncertainty and continue their lifelong learning process more effectively. Greater support for students can increase their learning ability and academic performance as students receive advice on strategies to better cope with academic stress [20, 21].

A new survey has been planned for the next months on the same group of people. It aims to analyse the changes that occurred in their teaching-learning experience.

Indeed, the COVID-19 pandemic caused a profound, structural change in higher education. There is the opportunity to improve online teaching-learning.

However, a research effort is needed to create effective online environments in which teachers and students can enter into a relationship.

Moreover, what will higher education be after the epidemic?

This question is an exciting research theme for the near future.

\section{ACKNOWLEDGEMENTS}

The research was carried out as part of the project "Adult Social Inclusion in a Digital Environment (ASIDE) Strategic Partnerships for Adult Education - Cooperation for innovation and exchange of good practices" No. 2019-1-PL01- KA204-065689, coordinated by Instytut Badań i Innowacji w Edukacji - INBIE. “The European Commission support for the production of this publication does not constitute endorsement of the contents which reflects the views only of the authors, and the Commission cannot be held responsible for any use which may be made of the information contained therein.”

\section{REFERENCES}

[1] UNESCO (2020, October 16). Why the world must urgently strengthen learning and protect finance for education, 2020, Available at https://en.unesco.org/news/why-world-musturgently-strengthen-learning-and-protect-finance-education

[2] C. Hodges, S. Moore, B. Lockee, T. Trust, \& A. Bond, The difference between emergency remote teaching and online learning. Educause review, 27, 1-12, 2020.

[3] F. Ahmadon, H. Ghazalli, I. M., \& H. Rusli, M. Studying during Pandemic: A Review of Issues from Online Learning in the Middle of COVID-19. In 2020 6th International Conference on Interactive Digital Media (ICIDM) (pp. 1-4). IEEE. December 2020.

[4] R. Ferdig, E. Baumgartner, R. Hartshorne, R. KaplanRakowski, \& C. Mouza, (Eds.). Teaching, technology, and teacher education during the COVID-19 pandemic: Stories from the field. Association for the Advancement of Computing in Education. 2020.

[5] J. Whalen, Should teachers be trained in emergency remote teaching? Lessons learned from the COVID-19 pandemic. Journal of Technology and Teacher Education, 28(2), 189-199. 2020.

[6] J. Azevedo, A. Hasan., D. Goldemberg, S. Iqbal, \& K. Geven, Simulating the potential impacts of COVID-19 school closures on schooling and learning outcomes: A set of global estimates. The World Bank, 2020.

[7] S. Huber, \& C. Helm, COVID-19 and schooling: evaluation, assessment and accountability in times of crises-reacting quickly to explore key issues for policy, practice and research with the school barometer. Educational Assessment, Evaluation and Accountability, 32(2), 237-270, 2020.

[8] M. Kuhfeld, J. Soland, Tarasawa, A. JohnsonRuzek, \& J. Liu, Projecting the potential impact of COVID-19 school closures on academic achievement. Educational Researcher, 49(8), 549565, 2020.

[9] F. García-Peñalvo, A. Corell, R. Rivero-Ortega, M. RodríguezConde \& N. Rodríguez-García, Impact of the COVID-19 on Higher Education: An Experience-Based Approach. In Information Technology Trends for a Global and Interdisciplinary Research Community. IGI Global, pp. 1-18, 2021.

[10] G. Marzano \& A. Zając, Managing education during the coronavirus emergency: the case of a polish higher education institution. Education. Innovation. Diversity. 1(1), 37-47. 2020.

[11] R. Quezada, C. Talbot, \& K. Quezada-Parker, From Bricks and Mortar to Remote Teaching: A Teacher Education Program's Response to COVID-19. Journal of Education for Teaching, 46(4), 472-483, 2020.

[12] S. Senel, \& H. Senel, Remote Assessment in Higher Education during COVID-19 Pandemic. International Journal, 8(2), 181199, 2021.

[13] C. Toquero, Challenges and Opportunities for Higher Education Amid the COVID-19 Pandemic: The Philippine Context. Pedagogical Research, 5(4), 2020.

[14] O. Zawacki-Richter, The current state and impact of Covid-19 on digital higher education in Germany. Human Behavior and Emerging Technologies, 3(1), 218-226, 2021.

[15] Z. Gródek-Szostak, M. Suder, A. Piechaczek, A., L. Ochoa Siguencia, Assessment and Comparison of Digital Competences in Education for Selected European Countries. European 
Environment. Technology. Resources. Rezekne, Latvia Proceedings of the $13^{\text {th }}$ International Scientific and Practical Conference. Volume 2, 162-168

Research Studies Journal, Volume XXIV, Special Issue 1, 348361. 2021.

[16] M. Gaebel, T. Zhang, H. Stoeber \& A. Morrisroe, Digitally Enhanced Learning And Teaching In European Higher Education Institutions, 2021. Available at: https://eua.eu/downloads/publications/digihe\%20survey\%20report.pdf

[17] L. Chen, E. Dorn, J. Sarakatsannis \& A. Wiesinger, Teacher survey: learning loss is global and significant. McKinsey \& Company. March 2021. Available at: https://www.mckinsey.com/industries/public-and-social-

sector/our-insights/teacher-survey-learning-loss-is-global-andsignificant?cid=other-eml-alt-mip-mck\&hdpid=1a57cf47-eae2400f-b9f0-

fd8edddbbfb6\&hctky=12238167\&hlkid=b53175decdec48bbb68 88bd21b5a168b

[18] G. Di Pietro, F. Biagi, P. Costa, Z. Karpinski \& J. Mazza, The likely impact of COVID-19 on education: Reflections based on the existing literature and recent international datasets (No. JRC121071). Joint Research Centre. 2020. Available at: https://core.ac.uk/download/pdf/343468109.pdf
[19] Z. Gródek-Szostak, L.Ochoa Siguencia, Z. Szelag-Sikora \& G. Marzano, The impact of industry 4.0 on the labor market. $61 \mathrm{st}$ International Scientific Conference on Information Technology and Management Science of Riga Technical University (ITMS) / eds.: Janis Grabis, Andrejs Romanovs, Galina Kulesova - Riga: Institute of Electrical and Electronics Engineers (IEEE), 1-5, 2020.

[20] Z. Gródek-Szostak, The poster as a form of active participation of students in the scientific movement. EDULEARN19 Proceedings / eds. by L. Gómez Chova, A. López Martínez, I. Candel Torre - Palma: International Association of Technology, Education and Development (IATED), 10630-10633Bozkurt, A., \& Sharma, R. C. (2020). Emergency remote teaching in a time of global crisis due to CoronaVirus pandemic. Asian Journal of Distance Education, 15(1), i-vi, 2019.

[21] I. Sania, Y. Hamza, Y. Chedid, J. Amalendran \& N. Hamzac, Understanding the consequence of COVID-19 on undergraduate medical education: Medical students' perspective. Annals of Medicine and Surgery, 58, 117-119, 2020. 